\title{
Agroindustry Residues as a Source for Cellulose Nanofibers Production
}

\author{
Mayra A. Mariño, ${ }^{a}$ Daniela Cypriano ${ }^{a}$ and Ljubica Tasic ${ }^{\oplus *, a}$ \\ ${ }^{a}$ Laboratório de Química Biológica, Departamento de Química Orgânica, Instituto de Química, \\ Universidade Estadual de Campinas (Unicamp), PO Box 6154, 13083-970 Campinas-SP, Brazil
}

\begin{abstract}
Our study was motivated by the large amount of crop residues produced in Brazil, which represent underutilized waste biomass and a serious threat to the environment because of the landfilling. For example, even though the corn crop is not popular in Brazil, it is produced in the area of around 18-20 million hectares with an average production of 5-6 $\mathrm{t} \mathrm{ha}^{-1}$. That is the reason to seek for the crop residues value-added applications as proposed in the present study. Four Brazilian crop waste biomass: orange bagasse, corn husks, sugarcane straw and coffee residues were used for cellulose nanofibers (CNF) production. CNFs were prepared using alkali treatment, followed by bleaching with sodium chlorite and extraction with oxalic acid. All steps were applied under moderate conditions of temperature and pressure, such as temperature of $120^{\circ} \mathrm{C}$ and below, water solutions with chemicals' concentrations lower that $10 \%$ and short sonication pulses. CNFs with diameters in the range 50-70 $\mathrm{nm}$ were obtained and products from orange bagasse and corn husks presented high crystallinity indexes (CI), 0.72 and 0.75 , respectively. The highest CNF yield was obtained from corn husks (38.5\%) followed by sugarcane straw (24.0\% with CI of 0.69). CNFs obtained from coffee residues showed a CI value of 0.65 after two bleaching steps. Different CNF morphologies were obtained according to the raw material. The four-crop waste biomass can be considered as excellent starting materials for CNF production in the four-steps process that adds new value to agro-industrial waste and might bring great economical valorization to Brazilian crops production.
\end{abstract}

Keywords: cellulose nanofibers, plant residues, micro-fibrillated cellulose

\section{Introduction}

Brazil is a country with many advantages for agriculture production due to the intense solar radiation and fertile soil. Therefore, a huge quantity of a biomass coming from different agricultural residues is generated per year, which by far are underutilized as resources for fine chemicals' production. Among the most cultivated crops, stand out oranges, coffee, sugar cane and corn, which leave around 80 million tons of waste per year. Brazilian production of oranges is the world greatest with over 8.35 million tons of orange waste formed per year. ${ }^{1}$ Some industries use this waste for citrus pulp pellets' production. The rests of corn and sugar produced in Brazil, which in 2018 corresponded to 8 and $20 \%$ of world production, respectively, ${ }^{2}$ such as corn husks and sugarcane bagasse, are mainly used to produce biogas and/or bioethanol. ${ }^{3}$ Besides, coffee produced in Brazil corresponded to about $32 \%$ of world production and its residues are less explored, ${ }^{2}$ mostly burned, disposed or used as fertilizers. Therefore, crops

*e-mail: ljubica@unicamp.br production involves the disposal of a great quantity of waste that instead of environment treating organic waste can be considered as potentially great source for production of many commodities, such as renewable fuels ${ }^{4}$ or different bio-based materials. Still, there are many challenges to overcome to explore any type of agriculture residues in economically attractive way. Up to now, this waste was mostly submitted to thermo-conversion, in furnaces and thermal power plants, used for land fertilization, cattle feed or explored as starting material for biofuel production.

Some agricultural residues might be explored for different bio-based material or polymer production, such as cellulose, hemicellulose, pectin, lignin. Almost all plant' residues are very rich in cellulose, which is their major component mainly organized in amorphous (less ordered) and crystalline microfibrils with crystallinity indexes (CI) of around 30-55\% in native cellulose ${ }^{5}$ and microfibrils' diameters of 20-100 $\mu \mathrm{m} .{ }^{6}$ Cellulose from this form (microfibrils bundles) can be nanonized into fibrils with nanoscopic dimensions after applying a mechanical treatment, such as shearing, high-pressure homogenization, cryo-crushing, among others. This nanoscale biopolymer 
presents high porosity besides good to excellent mechanical and rheological properties. ${ }^{7}$

Nanoscale cellulose is obtained by lignocellulose in two morphologically distinct forms with diameters of 20-100 nm, sometimes very long (100-1000 mm) and with aspect ratios between 10-100, which are called cellulose nanofibers (CNF). The other form is cellulose nanocrystals $(\mathrm{CNC})$ that show a rod-like distribution with high crystalline fractions, lengths between $50-350 \mathrm{~nm}$ and diameters in 10-100 $\mathrm{nm}$ range, with aspect ratio among $5-30.6,8 \mathrm{CNC}$ is usually obtained through more aggressive process prior to mechanical treatment, such as use of strong concentrated acids or hydrothermal processing, which employ high costs and great energy demands.

Other sources of cellulose are tunicates and algae, but there is also bacterial cellulose (BC), all of which lead to nanocellulose with crystallinities similar to $\mathrm{CNC}$ of around 0.7-0.8 and aspect ratio values from 50 to 150 , higher than CNF. Furthermore, a polymorphism $\mathrm{I}_{\beta}$ is associated with cellulose synthesized by tunicates such as sea squirt, while a polymorphism $\mathrm{I}_{\alpha}$ is associated with bacterial cellulose as well as cellulose from plants. ${ }^{9}$

Various raw material sources and methods for production of CNF have been studied ${ }^{10-12}$ and involve high shear homogenizer, cryo-crushing, grinding, microfluidization, electrospinning and microwave-assisted hydrolysis. According to the efficiency of the method used, the energy requirements and production cost for cellulose nanofibers (CNF) manufacturing can be up to 20 times higher than the costs of cellulose production. ${ }^{13}$ Therefore, research for cheaper yet effective processes for cellulose nanofibers' production is underway.

For example, there are many physical chemical treatments of biomass, which involve sequential extraction of other than cellulose biomaterials, such as hemicellulose, lignin or others, for CNF production. An alkaline treatment at moderate temperature and pressure conditions is generally applied to extract oligosaccharides (pulping step), low molecular mass compounds, some hemicellulose and a large fraction of lignin, which leaves a solid residue with low lignin content. Alkaline pretreatment is typically applied to degrade lignin but its efficiency depends on each recalcitrance biomass and the presence of other components more susceptible to degradation, such as sugars, pectin and tannins that interfere in the lignin dissolution, so that initially the native intermolecular linkages are partially fractionated at moderate conditions. ${ }^{14}$ The remaining lignin is thus removed in a second bleaching step of the process. Then, the cellulosic residue is usually treated by an acid, in general, concentrated sulfuric acid that yield CNC in harsh conditions $\left(64 \% \mathrm{v} / \mathrm{v}, 45-50{ }^{\circ} \mathrm{C}\right)$ in combination with a final mechanical step. ${ }^{15-19}$ Alternative mild chemical routes that have been used in combination with mechanical treatment to produce $\mathrm{CNF}$ are mainly enzymatic hydrolysis ${ }^{20}$ and 2,2,6,6-tetramethylpiperinidyl-1-oxyl (TEMPO) mediated oxidation, ${ }^{20}$ the latter is a treatment used to obtain derivatized CNF, which is less stable thermally but show higher tensile strength and elongation-at-break. ${ }^{21}$ These mild processes demand higher costs and rigorous control of the reaction conditions, thereby another alternative route is to apply a mild hydrolysis using organic acids that avoid glucose degradation that occurs with $64 \% \mathrm{H}_{2} \mathrm{SO}_{4}$. Besides, organic acids with lower acidity than sulfuric acid can as well selectively remove amorphous cellulose and have been less used for CNF isolation. ${ }^{22,23}$

$\mathrm{CNC}$ and CNF have several applications according to their physical characteristics, such as in hydrogels (porous scaffolds, optics, tissue engineering and dentistry additives), composites (packaging, construction materials, automotive accessories and electronic devices), thin films (electronic devices, membranes, antimicrobial filters, coatings, drug delivery and biosensors) and stabilizing agents of emulsions and foams (applications in food industry, pharmaceutical and cosmetology). ${ }^{24}$

Herein, four different agricultural wastes were investigated for $\mathrm{CNF}$ production using a sequential extraction in the four-steps process, which counted on autoclave conditions such as temperatures equal or below $120{ }^{\circ} \mathrm{C}$, use of the water diluted reagents at concentrations lower than $10 \%$ and short sonication pulses. The effects of the biomass chemical composition on the produced CNF morphology and crystallinity were compared for the feedstock valorization. The quality of the nanofibers obtained at applied moderate conditions was evaluated on the starting biomass lignin contents, once lignin was already recognized as CNF quality limiting factor. ${ }^{25}$

Four investigated biomass sources were orange bagasse, corn husks, sugarcane straw and coffee residues (husks and silver-skin). Characterizations of the CNF structural and morphological features were determined using scanning electron microscopy, X-ray diffraction (XRD), solid state cross-polarization magic angle spinning carbon-13 nuclear magnetic resonance spectroscopy (CP/MAS $\left.{ }^{13} \mathrm{C} \mathrm{NMR}\right)$ and thermogravimetric analysis.

\section{Experimental}

Materials

Coffee residues were provided by Faculdade de Engenharia Agrícola, sugarcane straw were provided by Faculdade de Engenharia Química, and corn husks were 
provided by Faculdade de Engenharia de Alimentos of University of Campinas, Brazil, while orange bagasse were obtained from a local restaurant (Campinas, Brazil) as bagasse in natura. These materials were dried at oven, ground and sieved to obtain a fraction of particle sizes lower than $1 \mathrm{~mm}$. Sodium hydroxide, sodium chlorite, sodium borate, sodium dodecyl sulfate, ethylenediamine tetraacetic acid (EDTA) and dibasic sodium phosphate were purchased from Labsynth (Diadema, Brazil). Triethylene glycol, $\alpha$-amylase and cetyl trimethyl ammonium bromide (CTAB) were provided by Sigma-Aldrich (São Paulo, Brazil). All chemicals used were reagent grade.

\section{Methods for determination of biomass composition}

\section{Determination of ash content}

Ash contents of biomass were calculated according to the Association of Official Analytical Chemists, ${ }^{26}$ which consists of heating about $5 \mathrm{~g}$ raw material in a furnace at $550{ }^{\circ} \mathrm{C}$ overnight.

\section{Determination of neutral detergent fibers (NDF)}

Filter bags (F57, ANKOM Technology, New York, USA) were weighed and about $0.50 \mathrm{~g}$ of dry samples were added for neutral fiber determination, which correspond to hemicellulose, cellulose and lignin, principally. Empty filter bags were used for calculation of the correction factor. All filter bags were closed by heating. The detergent aqueous solution was composed from sodium dodecyl sulfate $7.5 \% \mathrm{~m} / \mathrm{v}$ (SDS), $4.6 \% \mathrm{~m} / \mathrm{v}$ ethylenediamine tetra-acetic acid (EDTA), $1.7 \mathrm{~m} / \mathrm{v}$ sodium borate, $1.14 \% \mathrm{~m} / \mathrm{v}$ dibasic sodium phosphate (anhydrous) and $2.5 \% \mathrm{v} / \mathrm{v}$ triethylene glycol. At last, specific amounts of $2.5 \% \mathrm{~m} / \mathrm{v}$ sodium sulfide and $250 \mu \mathrm{L}$ per sample of heat-stable $\alpha$-amylase, for use in total dietary fiber assay (Aspergillus niger TDA-100A from Sigma, St. Louis, MO, USA), were added. Hydrolysis of the non-fibers fraction was performed at $100{ }^{\circ} \mathrm{C}$ for $75 \mathrm{~min}$ with the filter bags submerged in this solution in agitation on. Then, the filters bags were washed exhaustively with hot distilled water $\left(70-90^{\circ} \mathrm{C}\right)$ and placed in a beaker containing acetone for $5 \mathrm{~min}$. Then the acetone was evaporated, and filter bags were oven dried at $105^{\circ} \mathrm{C}$. The percentage of neutral detergent fiber (NDF), corresponding to cellulose, lignin and hemicellulose present in plant material (not pectin), was calculated using the following equation (equation 1): ${ }^{27}$

$\operatorname{NDF}(\%)=\frac{M 3-(\mathrm{M} 1 \mathrm{C} 1)}{\mathrm{M} 2} \times 100$

where, M1 = weight of the filter bag; M2 = weight of the filter bag with the sample; M3 = weight of the filter bag with the sample after NDF extraction; $\mathrm{C} 1=$ correction factor (average of empty bags after extraction/average empty bags before extraction).

\section{Determination of acid detergent fibers (ADF)}

Filter bags (F57, ANKOM Technology, New York, USA) were weighed and $0.50 \mathrm{~g}$ of residue from neutral detergent fiber (NDF) extraction was added. All filter bags were closed by heating. The acid detergent solution consisted of $5 \% \mathrm{~m} / \mathrm{v}$ CTAB dissolved in solution of $1 \mathrm{~mol} \mathrm{dm}^{-3}$ sulfuric acid $\left(\mathrm{H}_{2} \mathrm{SO}_{4}\right)$. Hydrolysis of the acid fibers, corresponding predominantly to hemicellulose fraction, was performed at $100{ }^{\circ} \mathrm{C}$ for $1 \mathrm{~h}$ with the filter bags submerged in this solution in agitation on. Then, the filters were washed exhaustively with hot distilled water $\left(70-90^{\circ} \mathrm{C}\right)$ and placed in a beaker containing acetone for $5 \mathrm{~min}$. After acetone evaporation, the filters were oven dried at $105{ }^{\circ} \mathrm{C}$. The percentage of acid detergent fiber, corresponding to cellulose and lignin content, was calculated using equation $2: 2^{27}$

$$
\operatorname{ADF}(\%)=\frac{M 3-(\mathrm{M} 1 \mathrm{C} 1)}{\mathrm{M} 2} \times 100
$$

where: M1 = weight of the filter bag; M2 = weight of the filter bag with the solid residue of NDF; M3 = weight of the filter bag with the sample after ADF extraction; $\mathrm{C} 1=$ correction factor (average of empty bags after extraction/ average empty bags before extraction).

\section{Determination of acid detergent lignin (ADL)}

After the determination of neutral detergent fibers (NDF) and acid detergent fibers (ADF) described above, filter bags were placed in a beaker with sufficient amount of $72 \% \mathrm{H}_{2} \mathrm{SO}_{4}$ solution. ${ }^{28}$ Filter bags were then submerged, and the solution was agitated occasionally every $30 \mathrm{~min}$. After $3 \mathrm{~h}$, the samples were washed exhaustively until neutral $\mathrm{pH}$, excess of water was removed, and the filters were soaked in a beaker containing acetone for $5 \mathrm{~min}$. After acetone evaporation, filters were dried in an oven at $105^{\circ} \mathrm{C}$. The percentage of acid detergent lignin was calculated using equation $3:^{27}$

$$
\operatorname{ADL}(\%)=\frac{M 3-(\mathrm{M} 1 \mathrm{C} 1)}{\mathrm{M} 2} \times 100
$$

where: M1 = weight of the filter bag; $\mathrm{M} 2$ = weight of the filter bag with the residue of ADF extraction; M3 = weight of the filter bag with the sample after ADL extraction; $\mathrm{C} 1$ = correction factor (average of empty bags after extraction/average empty bags before extraction). 
Procedure for preparation of cellulose nanofibers (CNF)

The first treatment was the thermochemical fractionation with $4 \% \mathrm{NaOH}$ solution. The alkaline suspension with $8 \% \mathrm{~m} / \mathrm{v}$ biomass was placed in an autoclave at $120{ }^{\circ} \mathrm{C}$ for $20 \mathrm{~min}$. After that, the solid residue was filtered and washed with distilled water. A second stage was bleaching with a solution of $1.7 \% \mathrm{~m} / \mathrm{v}$ sodium chlorite at $\mathrm{pH} 4.5$ $(8 \% \mathrm{~m} / \mathrm{v}$ biomass $)$ that took $20 \mathrm{~min}\left(120^{\circ} \mathrm{C}\right)$ to complete. Biomass residues from treatment with $\mathrm{NaOH}$ were white by this technique, except the one obtained from the coffee waste. Another round of bleaching was applied for coffee waste residue treated with $\mathrm{NaOH}$, but this time in alkaline conditions. A pH 10 solution of $6.5 \% \mathrm{~m} / \mathrm{v}$ hydrogen peroxide containing $10 \% \mathrm{~m} / \mathrm{v}$ coffee waste residue (treated with $\mathrm{NaOH}$ ) was heated at $80^{\circ} \mathrm{C}$ for $60 \mathrm{~min}$. After washing, the resulting bleached fibers from each biomass $(10 \% \mathrm{~m} / \mathrm{v})$ were subjected to a moderate acid extraction with a boiling solution of $5 \% \mathrm{~m} / \mathrm{v}$ oxalic acid for $60 \mathrm{~min}$ at $100{ }^{\circ} \mathrm{C}$.

The last step in CNF preparation was nanofibrillation, which was performed after neutralization of the bleached soda cellulosic products. Fibers were suspended in distilled water and sonicated 15 min using $20 \%$ of a pulse with $750 \mathrm{~W}$ and $20 \mathrm{kHz}$ (Sonics Vibra Cell, Champaign, IL, USA). Then, nanofibers were centrifuged at $10,000 \times \mathrm{g}$ for 15 min and dried by lyophilization (Terroni, São Carlos, Brazil) to proceed with their characterization.

\section{Characterization of cellulose nanofibers (CNF)}

\section{Structure analysis}

Lyophilized cellulose nanofibers from each biomass were analyzed using X-ray powder diffraction (XRD). A Shimadzu XRD-7000 X-ray diffractometer (Shimadzu, Columbia, MD, USA) operating at $40 \mathrm{kV}$ and $30 \mathrm{~mA}$ was used to obtain the diffraction profile in $2^{\circ} \mathrm{min}^{-1}$. Data were recorded using copper $(\mathrm{K} \alpha)$ radiation source and a secondary monochromator. CI were calculated according to following equation (equation 4): ${ }^{29}$

$$
\mathrm{CI}(\%)=\frac{\mathrm{I}_{200}-\mathrm{I}_{\mathrm{AF}}}{\mathrm{I}_{200}} \times 100
$$

where $I_{200}$ is the height of the 200 peak (at $2 \theta$ of approximately $22.6^{\circ}$ ), which is attributed to the crystalline domain and $\mathrm{I}_{\mathrm{AF}}$ is the minimum height (plateau) between the 200 and 101 peaks (at $2 \theta$ of approximately $18^{\circ}$, which correspond to amorphous fraction).

\section{NMR spectroscopy analysis}

Lyophilized cellulose nanofibers obtained from each biomass were analyzed by solid-state cross-polarization magic angle spinning (CP/MAS) carbon-13 nuclear magnetic resonance $\left({ }^{13} \mathrm{C} \mathrm{NMR}\right) .{ }^{13} \mathrm{C}$ NMR spectra were collected on a Bruker AMX-300 MHz instrument (Bruker, Billerica, MA, USA) operating at 7.05 T and 75.47 MHz with cross-polarization and $\mathrm{CP} / \mathrm{MAS}$. In $\mathrm{CP}$ pulse sequence, $3000 \mathrm{~Hz}$ MAS rate, a $90^{\circ}$ pulse for $1.5 \mathrm{~ms}$ and $800-\mathrm{ms}$ for contact pulse were used in spectrum acquisitions. The number of scans was 10,000 and $3.0 \mathrm{~s}$ delay were used for repetitions.

Crystallinity index (CI) was determined by line fitting using the deconvolution method assuming a Lorentzian line shape. C4-cellulose peak region corresponding to 86-92 ppm was assigned to crystalline cellulose, while the cellulose C4 total area (79-92 ppm) was used for calculating the CI, as reported by VanderHart and Atalla. ${ }^{30}$

\section{Morphological analysis}

Morphological features of the cellulose nanofibers from each biomass were investigated using a Quanta field emission scanning electron microscope 250 (FEI Quanta $^{\mathrm{TM}}$, Hillsboro, OR, USA). A drop (15 $\mu \mathrm{L})$ of suspended sample $(1 \%)$ was diluted in water $(1 \mathrm{~mL})$ and then one drop was deposited after ultrasonic shearing onto a silicon wafer in a sample stub, dried at room temperature and coated with gold using a MED 020 Sputter (BalTech, Balzers, Liechtenstein). Images were obtained using $10 \mathrm{kV}$ accelerating voltage and a secondary electron detector. The mean fiber diameters were determined using Image $1.490 .{ }^{31}$ For this purpose, 20 segments were randomly selected.

\section{Thermogravimetric analysis (TGA)}

Lyophilized CNF were analyzed by TGA using Q500 TG analyzer (TA Instruments, New Castle, DE, USA). Samples (about $6 \mathrm{mg}$ ) were heated in a pure nitrogen atmosphere (flow rate $60 \mathrm{~mL} \mathrm{~min}^{-1}$ ) from room temperature to $800{ }^{\circ} \mathrm{C}$ at a rate of $20^{\circ} \mathrm{C} \mathrm{min}^{-1}$.

\section{Results and Discussion}

\section{Biomass composition}

Lignocellulose biomass shows complex structure of cellulose fibers that are interconnected to hemicellulose, lignin and other organics. Robust and stable, lignin clings as cement other polysaccharides blocks (cellulose and hemicellulose), so that a biomass with a higher lignin content will have a higher recalcitrance to hydrolysis, ${ }^{25}$ therefore, it will be difficult to extract its other components and release cellulose. The separation of its fibers (holo- and hemicelluloses) requires a physicochemical pre-treatment in 
harsh or moderate conditions in which take place the partial hydrolysis of hemicelluloses and mostly the breakage of intermolecular linkages in lignin-carbohydrate complexes, which are mainly carbon-to-carbon bonds in lignin (ferulic acid) and ester/ether bonds in carbohydrate complexes. ${ }^{24}$

Data depicted in Table 1 show that agricultural residues analyzed herein presented high cellulose contents with an exception of orange bagasse. The orange bagasse biomass presented low lignin and high soluble fractions' percentages, such as pectin and hemicellulose fractions. In contrast, the other three lignocellulosic wastes presented high cellulose contents, which might cause better yields of CNF. However, their higher lignin contents might demand somewhat harsher conditions for cellulose isolation. For example, sugarcane straw showed the highest lignin content and had been less explored for this biomaterial production, but also presented a similar chemical composition to sugarcane bagasse, a widely investigated biomass for cellulose nanocrystals (CNC) production. Whereas corn husks stand out with the highest cellulose content and a low fraction of lignin.

After applying the sequence for cellulose nanofibers extraction (Figure 1), consisting in alkaline treatment, bleaching, acid hydrolysis, sonication and lyophilization, a solid material of low density and white coloration was obtained (Supplementary Information (SI) section, Figure S1). However, after two steps of bleaching, the product from coffee residue did not show a white appearance. It could be due to the high insoluble lignin content and high insoluble tannins in this material. ${ }^{32,33}$

\section{Structure analysis of cellulose nanofibers}

Two analytical techniques were used to determinate CI for CNF samples: XRD and CP/MAS ${ }^{13} \mathrm{C}$ NMR. CI is an important parameter for nanocellulose materials concerning their reinforcement properties in formation of composites. ${ }^{34}$ In order to compare the amorphous portion removed from each raw material, which correspond mainly to hemicellulose and pectin removal during the treatment with $\mathrm{NaOH}$ (4\% solution), and lignin removal during bleaching, $\mathrm{X}$-ray diffraction data were used for estimations and comparison of the CI values according to the literature. ${ }^{35-37}$

Figure 2 shows the peaks related to crystalline cellulose and the depression associated to the amorphous fraction of

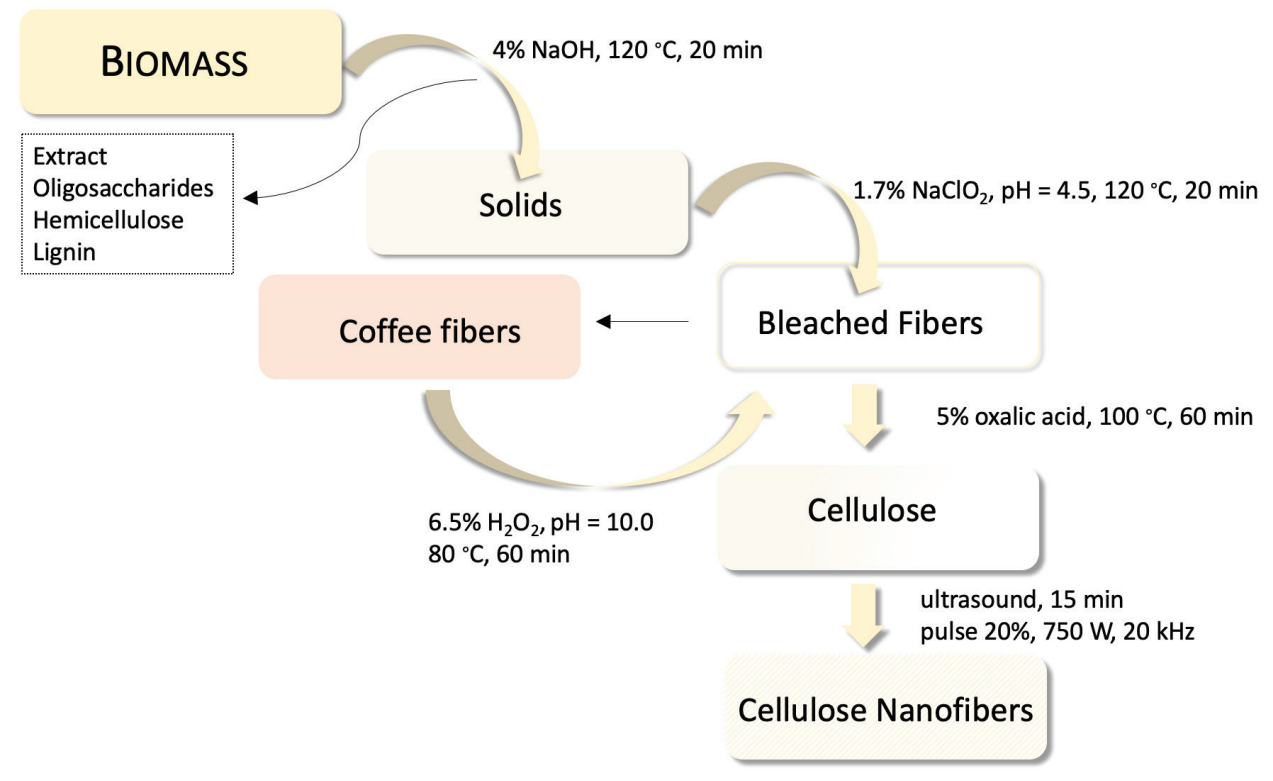

Figure 1. Illustration of the process used for cellulose nanofibers production.

Table 1. Chemical composition of raw materials used for cellulose nanofibers (CNF) production

\begin{tabular}{lcccc}
\hline $\begin{array}{l}\text { Characterization of } \\
\text { agroindustry residues }\end{array}$ & Corn husks & Coffee residues & Orange bagasse & Sugarcane straw \\
\hline Ash / \% & $3.6 \pm 0.3$ & $7.1 \pm 0.3$ & $3.9 \pm 1.0$ & $3.8 \pm 0.2$ \\
Soluble fraction / \% & $8.2 \pm 0.5$ & $9.3 \pm 1.0$ & $48.1 \pm 2.1$ & $0.2 \pm 0.2$ \\
Lignin / \% & $10.4 \pm 0.3$ & $15.0 \pm 0.8$ & $4.4 \pm 0.2$ & $21.6 \pm 2.4$ \\
Cellulose / \% & $40.6 \pm 0.8$ & $38.3 \pm 1.0$ & $16.9 \pm 2.7$ & $39.8 \pm 3.2$ \\
Hemicellulose / \% & $37.2 \pm 0.8$ & $30.2 \pm 1.3$ & $17.6 \pm 2.0$ & $33.3 \pm 3.0$ \\
\hline
\end{tabular}




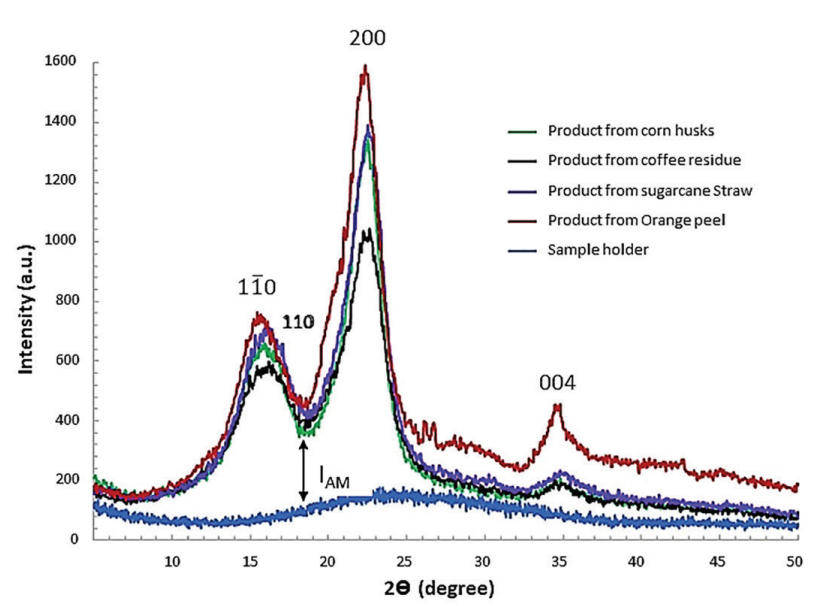

Figure 2. X-ray diffractograms (XRD) data for CNFs obtained from orange bagasse (red), corn husks (green), sugarcane straw (purple) and coffee residues (black).

cellulose structure. CI calculated using Segal method are presented in Table 2.

The highest value for CI was obtained for the CNF produced from corn husks, followed by CNF from orange bagasse and sugarcane straw. By these results, it was evident that a lignocellulosic biomass that presented high cellulose content and low lignin content, like the corn husks, allowed to produce CNF in a higher yield (38.5\%) and with the highest CI (0.75), respectively. Nevertheless, the yield for the CNF from orange bagasse was the lowest $(10.8 \%)$, this biomass presented the lowest lignin content and CNF showed high CI by XRD (0.72), so removal of its amorphous portions was excellent. In contrast, sugarcane straw had the highest lignin content and due to the proportion of this component, the CNF yield (24.0\%) and crystallinity were lower (69.3\%). Cellulose nanofibers from coffee residues presented a particular case, once it was not possible to achieve their complete bleaching and CNF quality was the lowest one with the CI of 0.65 . Nevertheless, the CI superior than 0.6 or $60 \%$ are considered adequate for any nanoscale cellulose (nanofibers or nanocrystals).

Just a few studies have been found in the literature on cellulose nanofibers extracted from coffee husks and sugarcane straw. The first reported study by Sung et al. ${ }^{18}$ explored coffee silverskin as a raw material, which is tegument of the green beans and the primary by-product of coffee roasting process. They obtained CNC through a similar process performed in more aggressive conditions, with acid treatment $\left(64 \% \mathrm{H}_{2} \mathrm{SO}_{4}\right)$ applied at $45{ }^{\circ} \mathrm{C}$ for 30 min. Other study ${ }^{35}$ explored coffee husks at reflux temperature for alkaline cooking, an exhausted bleaching at reflux temperature for about $24 \mathrm{~h}$, an acid treatment with $\mathrm{H}_{2} \mathrm{SO}_{4}(64 \%)$ and additional step of ultrasonic shearing for $30 \mathrm{~min}$. These processes resulted in CNC with mean diameters of 8-20 nm and CI of 0.72-0.92, somewhat higher when compared to the results reported herein $(0.65)$ from coffee residues (husks and silverskin). It is possible to assume that coffee silverskin is a more recalcitrance biomass and due to that, even after harsher bleaching and acid treatments, CNF with a lower CI were produced by hydrolysis with $5 \%$ oxalic acid.

Corn stover combines stalks, straw, cob and husks, so it can be considered as a global by-product from corn. One pioneer investigation at moderate conditions was performed with corn stalks by an alkaline treatment bleaching and a step of acid treatment, using a mixture of $1: 1(\mathrm{v} / \mathrm{v}) 10 \%$ nitric acid and $10 \%$ chromic acid for $5 \mathrm{~min}$ at $60{ }^{\circ} \mathrm{C}$. Cellulose fibers with width of about $20 \mu \mathrm{m}$ were observed with $74 \%$ of crystallinity by this procedure without application of a fibrillation stage.$^{36}$ Herein, corn straw was processed for CNF production in moderate conditions, while Rehman et al. ${ }^{37}$ had already applied a similar processing in an autoclave with $5 \% \mathrm{NaOH}$, bleaching by $\mathrm{H}_{2} \mathrm{O}_{2}$ and tested different times but used an additional step with acid in high concentration and low temperature $\left(64 \% \mathrm{H}_{2} \mathrm{SO}_{4}\right.$ at $25^{\circ} \mathrm{C}$ for $\left.15-180 \mathrm{~min}\right)$. The aforementioned process produced $\mathrm{CNC}$ (whiskers) with diameter of $19 \pm 2 \mathrm{~nm}$ and $\mathrm{CI}$ of 0.79 , the same CI as reported herein. Another study ${ }^{38}$ was related to corn straw in an eightstep alkali treatment with $\mathrm{KOH}$, bleaching and fibrillation. $\mathrm{CNF}$ ribbon-like bundle twists and with diameters range from 2 to $5 \mathrm{~nm}$ were obtained.

An alkaline pretreatment at moderate conditions coupled with diluted acid hydrolysis/fibrillation have been suitable for CNF production using residues as bamboo, ${ }^{39}$ banana peel, ${ }^{40}$ rice straw, ${ }^{41}$ corn straw,${ }^{38}$ carrot residue from juice industry, ${ }^{41}$ beer brewing residue, ${ }^{41}$ and orange peel..$^{42}$

Table 2. Yield and crystallinity index (CI) values for cellulose nanofibers (CNFs) obtained after physical chemical treatment (alkaline treatment, bleaching and acid treatment) and ultrasonic fibrillation

\begin{tabular}{lcccc}
\hline $\begin{array}{l}\text { Characteristics of cellulose } \\
\text { nanofibers }\end{array}$ & Orange bagasse & Corn husks & Sugarcane straw & Coffee residues \\
\hline Yield / \% & 10.8 & 38.5 & 24.0 & 33.0 \\
CI by XRD & 0.72 & 0.75 & 0.69 & 0.65 \\
CI by NMR & 0.48 & 0.50 & 0.46 & - \\
\hline
\end{tabular}

XRD: X-ray diffraction; NMR: nuclear magnetic resonance spectroscopy. 
The conditions and CNF features obtained in some previous studies for comparison with our results are summarized in Table 3. Through these data it can be seen that the bleaching stage must be carried out after the alkaline pretreatment, since in this way the residual lignin is efficiently removed in a single step, except for coffee residue which demanded harsher bleaching conditions. Furthermore, an additional alkaline treatment step does not contribute significantly to the increase in crystallinity, so dilute or concentrated acid hydrolysis is preferable. ${ }^{42}$

Sugarcane bagasse as raw material has been tested for $\mathrm{CNC}$ production using the common acid treatment (solution $64 \% \mathrm{H}_{2} \mathrm{SO}_{4}$, for $60 \mathrm{~min}$, at $45^{\circ} \mathrm{C}$ ) and different conditions during alkaline treatment and bleaching. Kumar et al. ${ }^{43}$ reported a two-step alkaline treatment followed by acid treatment $(64 \% \mathrm{~m} / \mathrm{v})$ and sonication in neutral $\mathrm{pH}$ for $10 \mathrm{~min}$. By this sequential treatment, rod-like $\mathrm{CNC}$ with average diameter of $4 \mathrm{~nm}$ and high crystallinity $(87.5 \%)$ were obtained.

A chemical treatment was reproduced by Sofla $e t$ al..$^{12}$ for sugarcane bagasse. It was investigated which mechanical method is better for size reduction: acid treatment with sonication or ball milling. Rope-like form of CNF was obtained by ball milling with mean diameters of $50 \mathrm{~nm}$ and $68 \%$ of crystallinity, while applied acid treatment and sonication resulted in $\mathrm{CNC}$ with diameters between $20-30 \mathrm{~nm}$ and $73 \%$ of crystallinity. In our study, the resulting material from sugarcane straw presented a higher crystallinity using an acid solution at low concentration at higher temperature $\left(100{ }^{\circ} \mathrm{C}\right)$.

Another demonstration that physical chemical conditions had a greater positive effect over crystallinity than a high acid concentration was developed by Teixeira et al. ${ }^{19}$ Once sugarcane bagasse underwent alkaline cooking, and after bleaching using alkaline peroxide solution, the fibers were submerged into solution of $6 \mathrm{~mol} \mathrm{~L}^{-1} \mathrm{H}_{2} \mathrm{SO}_{4}\left(45^{\circ} \mathrm{C}\right.$ for $30 \mathrm{~min}$ ), resulted in cellulose whiskers with diameters of $4 \mathrm{~nm}$ and $87.5 \%$ of crystallinity. Another important observation related to this publication was a decrease in the $\mathrm{CI}$ after 75 min of acid treatment associated to degradation, as well as higher diameters of $8 \mathrm{~nm}$.

Pre-treated orange bagasse had been evaluated before for CNF production by acid hydrolysis in solution $5 \% \mathrm{H}_{2} \mathrm{SO}_{4}$. A higher CI value was obtained (0.79) after longer cooking $(60 \mathrm{~min})$ in boiling conditions instead of 30 min and an additional step in acid mild conditions as pre-treatment to obtain free-pectin pulp. ${ }^{42}$

Table 3. Results of studies using moderate conditions for CNF production

\begin{tabular}{|c|c|c|}
\hline Source & Sequential processing & Characteristics of CNF \\
\hline Bamboo $(\text { Chen } \text { et al. })^{38}$ & $\begin{array}{l}\text { ten-step: sodium chlorite treatment at } 75{ }^{\circ} \mathrm{C} \text { for } 1 \mathrm{~h} \\
\text { (six times), } 2 \% \mathrm{KOH} \text { solution at } 90^{\circ} \mathrm{C} \text { for } 2 \mathrm{~h}, 5 \% \\
\mathrm{KOH} \text { solution at } 90{ }^{\circ} \mathrm{C} \text { for } 2 \mathrm{~h} \text {, hydrolysis by } 1 \% \mathrm{HCl} \\
\text { at } 80{ }^{\circ} \mathrm{C} \text { for } 2 \mathrm{~h} \text { and ultrasonication for } 30 \mathrm{~min}\end{array}$ & $\begin{array}{l}\text { the diameters range from } 30 \text { to } 80 \mathrm{~nm},>1 \mathrm{~mm} \\
\text { in length, crystallinity of about } 61 \% \text { and thermal } \\
\text { degradation temperature of about } 309^{\circ} \mathrm{C} \\
\text { morphology: straight nanofibrils and some aggregates }\end{array}$ \\
\hline Banana peel (Tibolla et al.) ${ }^{39}$ & $\begin{array}{l}\text { five-step: } 5 \% \mathrm{NaOH} \text { solution at room temperature for } \\
14 \mathrm{~h} \text { (twice), bleaching by } 1 \% \mathrm{NaClO}_{2} \text { at } 70{ }^{\circ} \mathrm{C} \text { for } 1 \mathrm{~h} \\
\text { (twice) and hydrolysis by } 1 \% \mathrm{H}_{2} \mathrm{SO}_{4} \text { at } 80{ }^{\circ} \mathrm{C} \text { for } 1 \mathrm{~h}\end{array}$ & $\begin{array}{l}\text { average diameter of } 10.9 \mathrm{~nm} \text {, length of } 455 \mathrm{~nm} \text { and } \\
\text { crystallinity of } 58.6 \% \\
\text { morphology: network of long entangled filaments }\end{array}$ \\
\hline Corn straw/rice straw $(\text { Chen } \text { et al. })^{40}$ & $\begin{array}{l}\text { eight-step: bleaching by sodium chlorite at } 75^{\circ} \mathrm{C} \text { for } \\
1 \mathrm{~h} \text { (four times), } 3 \% \mathrm{KOH} \text { at } 90^{\circ} \mathrm{C} \text { for } 1 \mathrm{~h}, 8 \% \mathrm{KOH} \\
\text { solution at } 90^{\circ} \mathrm{C} \text { for } 1 \mathrm{~h} \text { and fibrillation for } 20 \mathrm{~min}\end{array}$ & $\begin{array}{c}\text { the diameters range from } 2 \text { to } 5 \mathrm{~nm} \text { and length of the } \\
\text { bundles was }>11 \mu \mathrm{m} \\
\text { crystallinity was not evaluated, morphology: twisted } \\
\text { regions and ribbon-like bundle twists }\end{array}$ \\
\hline $\begin{array}{l}\text { Carrot residue/beer residue } \\
(\text { Berglund } \text { et al. })^{41}\end{array}$ & $\begin{array}{l}\text { four step/six-step: boiled at } 85^{\circ} \mathrm{C}, 2 \% \mathrm{NaOH} \text { at } 80^{\circ} \mathrm{C} \\
\text { for } 2 \mathrm{~h} \text {, bleaching by } 1.7 \% \mathrm{NaClO}_{2} \text { at } 80{ }^{\circ} \mathrm{C} \text { for } 2 \mathrm{~h} \\
\text { (three times for beer residue) and grinding treatment } \\
(20 \mathrm{~min} \text { for carrot and } 170 \mathrm{~min} \text { for beer residue) }\end{array}$ & $\begin{array}{l}\text { carrot residue: the diameters range from } 5 \text { to } 30 \mathrm{~nm} \\
\text { and crystallinity was } 77 \% \\
\text { morphology: network of long entangled filaments } \\
\text { beer residue: the diameters range from } 10 \text { to } 40 \mathrm{~nm} \\
\text { and crystallinity was } 74 \% \\
\text { morphology: network of long entangled filaments }\end{array}$ \\
\hline Orange peel (Mariño et al. . $^{42}$ & $\begin{array}{l}\text { five-step: boiled at pH } 2,2 \% \mathrm{NaOH} \text { at } 120^{\circ} \mathrm{C} \\
\text { for } 20 \mathrm{~min} \text {, bleaching by } 1.7 \% \mathrm{NaClO}_{2} \text { at } 80^{\circ} \mathrm{C} \\
\text { for } 30 \mathrm{~min}, 5 \% \mathrm{H}_{2} \mathrm{SO}_{4} \text { at } 100{ }^{\circ} \mathrm{C} \text { for } 60 \mathrm{~min} \text { and } \\
\text { sonication for } 15 \mathrm{~min}\end{array}$ & $\begin{array}{l}\text { the mean diameter was } 18.4 \mathrm{~nm} \text { and crystallinity } 79 \% \\
\text { morphology: network of long entangled filaments }\end{array}$ \\
\hline $\begin{array}{l}\text { Corn straw/orange peel/sugarcane } \\
\text { straw (this study) }\end{array}$ & $\begin{array}{l}\text { four-step: } 4 \% \mathrm{NaOH} \text { solution at } 120^{\circ} \mathrm{C} \text { for } 20 \mathrm{~min} \text {, } \\
\text { bleaching by } 1.7 \% \text { sodium chlorite solution at } 120^{\circ} \mathrm{C} \\
\text { for } 20 \mathrm{~min} \text {, hydrolysis by } 5 \% \text { oxalic acid at } 100{ }^{\circ} \mathrm{C} \text { for } \\
60 \mathrm{~min} \text { and ultrasonication for } 15 \mathrm{~min}\end{array}$ & $\begin{array}{l}\text { the diameters range from } 50 \text { to } 70 \mathrm{~nm} \text { and } \\
\text { crystallinities range from } 69 \text { to } 75 \% \\
\text { morphology: network of long entangled nanofibers } \\
\text { for CNF from orange peel and sugarcane straw, while } \\
\text { CNF from corn straw were straight rod-like nanofibrils }\end{array}$ \\
\hline
\end{tabular}

CNF: cellulose nanofibers. 
Another way to obtain free-pectin pulp from orange peel, after alkaline pretreatment and bleaching, had been the enzymatic hydrolysis with commercial pectinase, which leaded to CNFs with diameters range from 10 to $50 \mathrm{~nm}$ in a network of long entangled filaments with crystallinity of $59.2 \%$ after a grinding treatment. ${ }^{44} \mathrm{~A}$ later approach was made by using pectinase extracted from native bacteria that usually attack orange peel. After sonication, CNFs with approximately $55 \%$ crystallinity and an average diameter of $10 \mathrm{~nm}$ were observed. ${ }^{45}$

\section{NMR analysis of cellulose nanofibers (CNFs)}

At last, CNF analysis was done by NMR for solid state (CP/MAS ${ }^{13} \mathrm{C}$ NMR). Figure 3 shows the CNF profiles by ${ }^{13} \mathrm{C}$ NMR. Signal splitting is characteristic for $\mathrm{C} 4$ and C6 carbons. Deconvoluted C4 signals were used for CI determination. Observing the NMR spectra, it was verified that the CNF material showed to be pure, once no signals appeared in the regions of carbonyl groups (170-180 ppm), aliphatic groups (20-30 ppm), characteristics groups of hemicellulose, pectin and/or lignin..$^{46,47}$

Lower values of crystallinity were obtained by deconvolution method using NMR, ${ }^{47,48}$ thereby decreasing order of the values was conserved (Table 2). The highest $\mathrm{CI}$ value for cellulose nanofibers from corn husks and the lowest value for cellulose nanofibers from sugarcane straw were obtained. The determinations of CI from XRD data were used for comparison with previous studies, ${ }^{35-42}$ once this technique is usually more accessible for this purpose of structural analysis. Although, amorphous regions of XRD data may be attributed to hemicellulose, pectin, cellulose or lignin, thus by NMR technique is possible to know only the contribution of amorphous region from cellulose as well as to detect the presence or other biomacromolecules.

\section{Morphological characterization}

Cellulose nanofibers produced from four agricultural waste were examined by scanning electron microscopy (SEM) for determination of their shapes and sizes.

Applying a short pulse of 15 min after a mild chemical procedure, different CNF morphologies were obtained according to the raw material used. The obtained CNF from orange bagasse were characterized as dense as illustrated in Figure 4. Long in length and organized in a net-like form in tangled bundles were the CNF from orange bagasse and sugarcane straw (Figures 4a-4d).

Analogous heterogeneous network structure of CNF with widths between $10-50 \mathrm{~nm}$ were also reported by hydrolysis of cellulose from sugarcane bagasse with $64 \%$ sulfuric acid; ${ }^{12,43,49}$ while Mariño et al. ${ }^{42}$ obtained CNF from orange bagasse using 5\% sulfuric acid. These results show that despite having applied hydrolysis with concentrated acid to cellulose from sugarcane bagasse, homogeneous $\mathrm{CNF}$ or $\mathrm{CNC}$ were not obtained from biomass with a high lignin content at moderate conditions. Thus, obtaining homogeneous CNF from high lignin biomass at moderate conditions as sugarcane straw has been observed only through an intensive enzymatic deconstruction or a sophisticated technique like high pressure homogenization and electrospun. ${ }^{50}$

CNF from orange bagasse, sugarcane straw and corn husks showed mean diameters of 74.7 \pm 9.0, $57.5 \pm 13.0$
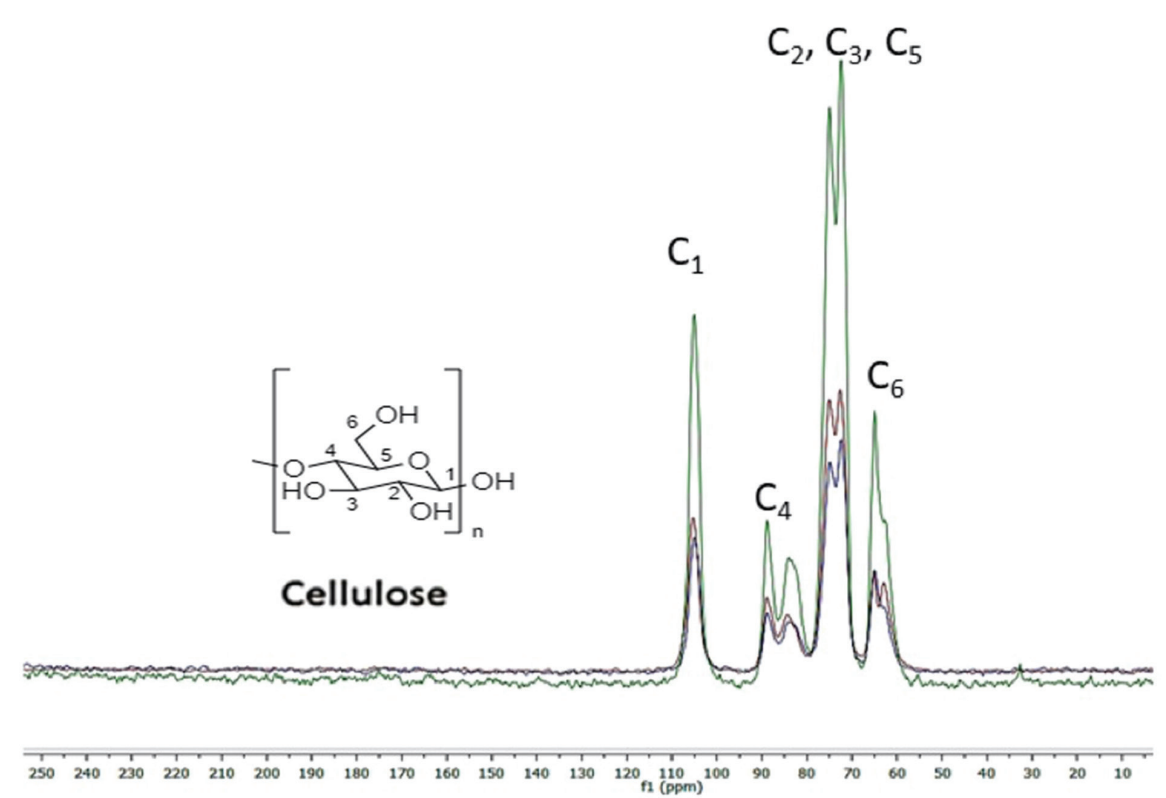

Figure 3. Cellulose nanofibers $(\mathrm{CNF}){ }^{13} \mathrm{C}$ NMR spectra (CP/MAS). In red: $\mathrm{CNF}$ from orange bagasse, in green: $\mathrm{CNF}$ from corn husks, and in blue: $\mathrm{CNF}$ from sugarcane straw. 

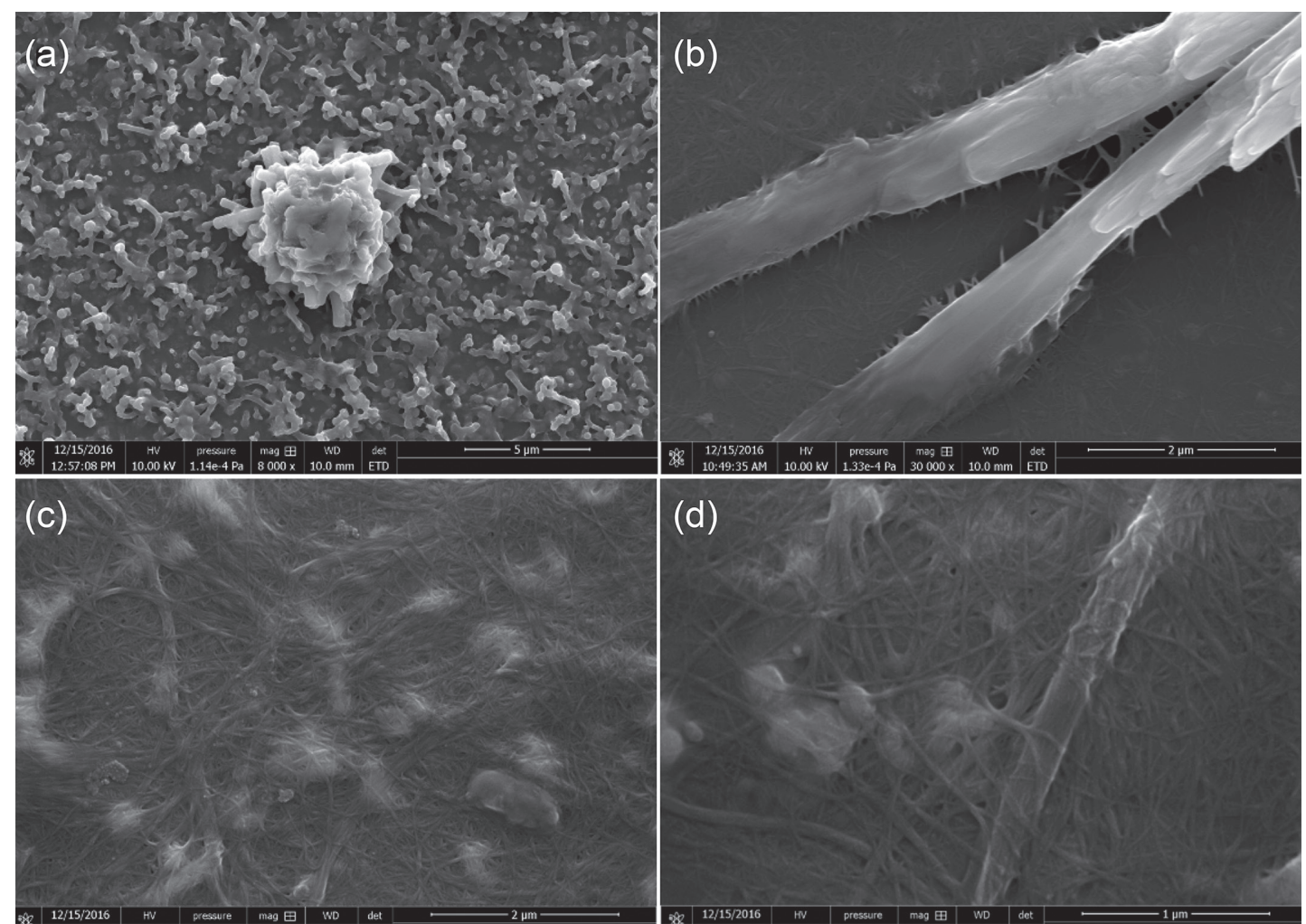

Figure 4. Morphology of the cellulose nanofibers (CNF) isolated from orange bagasse (a) $5 \mu \mathrm{m}$ and (b) $2 \mu \mathrm{m}$; CNF isolated from sugarcane straw (c) $2 \mu \mathrm{m}$ and (d) $1 \mu \mathrm{m}$.

and $51.9 \pm 11.0 \mathrm{~nm}$, respectively. Cellulose nanofibers from corn husks presented shape similar to other nanofibers with less number of bundles microfibers (Figure 5), which resulted in a more homogeneous nanomaterial, straight nanofibrils as was reported by Chen et al. ${ }^{38}$ and high CI value (0.75). CNF with mean diameters of $52 \mathrm{~nm}$, greater than usual, were probably obtained because of moderate conditions used in their production. When compared to the results from Reddy and Yang, ${ }^{36}$ a similar morphology of CNF and CI of 0.74 were obtained applying acid hydrolysis combined with maceration at $60{ }^{\circ} \mathrm{C}$ overnight, in a $1: 1$ mixture of $10 \%$ nitric acid and $10 \%$ chromic acid. It could be deduced that a homogeneous product can be obtained using moderate hydrolysis combined with maceration. It was noted that the effects of the acid type and its concentration has influenced greatly over the size of the crystals more than over CI values for CNF.

$\mathrm{CNFs}$ in the highest yields with the best morphological and the highest crystallinity index were obtained from the corn husks. The results of thermal analysis (Figure S2, SI section) for this CNFs showed first transition that corresponded to evaporation of CNF-bound water (around $100{ }^{\circ} \mathrm{C}$ ), while the main transition occurred between $250-370{ }^{\circ} \mathrm{C}$, followed by decomposition at temperatures higher than $600{ }^{\circ} \mathrm{C}$ that left ashes. The main transition also presented a small split transition that occurred after $350{ }^{\circ} \mathrm{C}$, which could be
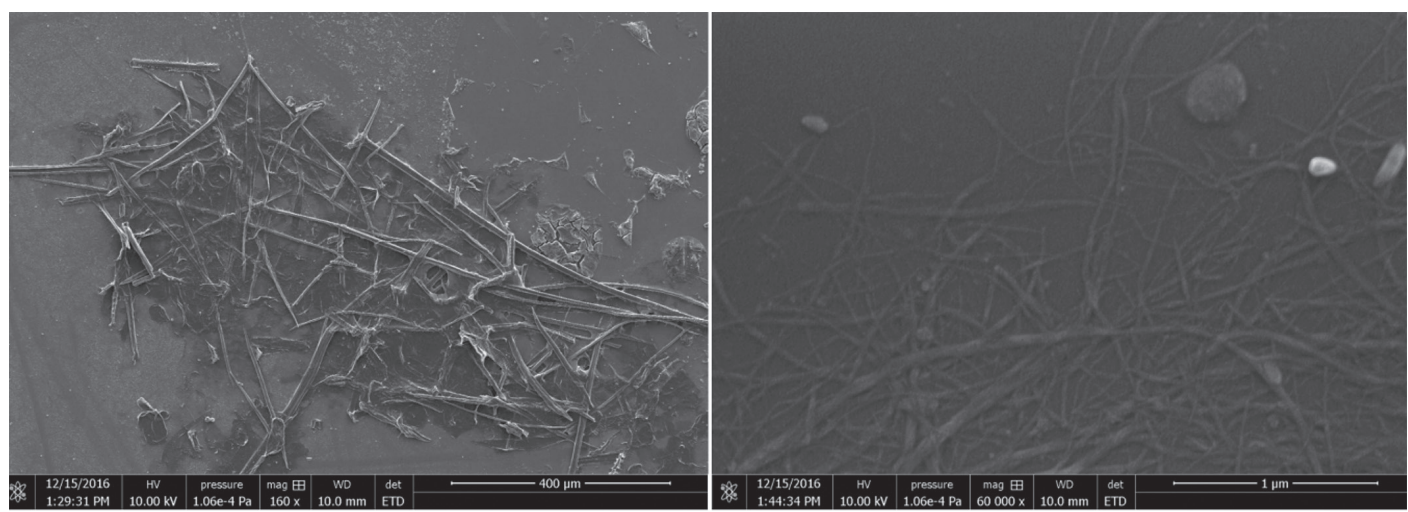

Figure 5. Morphology of CNF from corn husks (left: $400 \mu \mathrm{m}$ and right: $1 \mu \mathrm{m}$ ). 
attributed to the decomposition of the crystalline CNFs, while the main decomposition corresponded to the transition of the anhydroglucuronate units. ${ }^{51} \mathrm{~A}$ remarkable thermostability of CNFs is related to a high polymerization degree due to large diameter of $10-100 \mathrm{~nm}^{52}$

\section{Conclusions}

Four abundant agroindustry waste materials were studied for potential production of cellulose nanofibers under physical-chemical treatment at moderate temperature and pressure conditions. Sugarcane straw, corn husks, coffee residues and orange bagasse could be used for preparation of $\mathrm{CNF}$ in high yield, with good thermostability and excellent crystallinities. An efficient four-step process counted on diluted sodium hydroxide (4\%), bleaching, acid treatment with 5\% oxalic acid, and nanofibrillation in moderate conditions. The proposed process is relatively cheap, fast and simple. Just CNF obtained from the coffee residues underwent the second bleaching step and took longer to complete. The best yield and characteristics were observed for the CNF obtained from corn husks. Therefore, instead of land filling or thermo-conversion, waste from agroindustry is a promising feedstock to explored for fine chemicals production, as for example, an ideal material for cellulose nanofibers production.

\section{Supplementary Information}

Supplementary information is available free of charge at http://jbcs.sbq.org.br as PDF file.

\section{Acknowledgments}

The authors thank to the funding agencies: Coordenação de Aperfeiçoamento de Pessoal de Ensino Superior (CAPES), Conselho Nacional de Pesquisa (CNPq) and Fundação de Amparo à Pesquisa do Estado de São Paulo (FAPESP).

\section{References}

1. Leitão, V. F.; Gottschalk, L. M. F.; Ferrara, M. A.; Nepomuceno, A. L.; Molinari, H. B. C.; Bom, E. P. S.; Waste Biomass Valorization 2010, $1,65$.

2. https://www.fas.usda.gov/data/world-agricultural-production, accessed in November 2020.

3. Rezzadori, K.; Benedetti, S.; Amante, E. R.; Food Bioprod. Process. 2012, 90, 606.

4. Lora, E. E. S.; Ayarza, J. A. C.; Cortez, L. A. B.; Biomassa para Energia; Editora Unicamp: Campinas, 2008.
5. Nogueira, M. F. M.; Rendeiro, G.; Barreto, E. J. F.; Combustão e Gaseificação da Biomassa Sólida: Soluções Energéticas para a Amazônia, $3^{\text {rd }}$ ed.; Ministério de Minas e Energia: Brasília, 2008.

6. Preston, R. D.; Discuss. Faraday Soc. 1951, 11, 165.

7. Poletto, M.; Ornagui, H.; Zattera, A. J.; Materials 2014, 7, 6105.

8. Foster, E. J.; Moon, R. J.; Agarwal, U. P.; Bortner, M. J.; Bras, J.; Camarero-Espinosa, S.; Chan, J. K.; Clift, M. J.; Cranston, E.; Eichhom, S. J.; Fox, D. M.; Hamad, W. Y.; Heux, L.; Jean, B.; Korey, M.; Nieh, W.; Ong, K. J.; Reid, M. S.; Renneckar, S.; Roberts, R.; Shatkin, J. A.; Simonsen, J.; Stinson-Bagby, K.; Wanasekara, N.; Youngblood, J.; Chem. Soc. Rev. 2018, 47, 2609.

9. Sacui, I. A.; Nieuwendaal, R. C.; Burnett, D. J.; Stranick, S. J.; Jorfi, M.; Weder, C.; Foster, E. J.; Olsson, R. T.; Gilman, W. J.; ACS Appl. Mater. Interfaces 2014, 6, 6127.

10. Kargarzadeh, H.; Mariano, M.; Huang, J.; Lin, N.; Ahmad, I.; Dufresne, A.; Thomas, S.; Polymer 2017, 132, 368.

11. Abbate, F.; Iulianelli, G.; Bruno, M. I.; Mater. Sci. Appl. 2016, 7, 257.

12. Sofla, M. R. K.; Brown, R. J.; Tsuzuki, T.; Rainey, T. J.; $A d v$. Nat. Sci.: Nanosci. Nanotechnol. 2016, 7, 035004.

13. Kaila, S.; Dufresne, A.; Cherian, B. M.; Kaith, B. S.; Avérous, L.; Njuguna, J.; Nassiopoulos, E.; Int. J. Polym. Sci. 2011, 1, 35.

14. Rollin, J. A.; Zhu, Z.; Sathitsuksanoh, N.; Percival, Z. Y. H.; Biotechnol. Bioeng. 2011, 108, 22.

15. https://www.istoedinheiro.com.br/noticias/negocios/20160506/ formula-crescimento-fibria/370214, accessed in November 2020.

16. Rosa, M. F.; Medeiros, E. S.; Malmonge, J. A.; Gregorski, K. S.; Wood, D. F.; Mattoso, L. H. C.; Glenn, G.; Orts, W. J.; Imam, S. H.; Carbohydr. Polym. 2010, 81, 83.

17. Silvério, H. A.; Flauzino, W. P.; Oliveira, N. D.; Pasquini, D.; Ind. Crops Prod. 2013, 44, 427.

18. Sung, S. H.; Chang, Y.; Han, J.; Carbohyd. Polym. 2017, 169, 495.

19. Teixeira, E. M.; Bondancia, T. J.; Teodoro, K. B. R.; Correa, A. C.; Marconcini, J. M.; Mattoso, L. H. C.; Ind. Crops Prod. 2011, 33, 63 .

20. Costa, L. A. S.; Fonsêca, A. F.; Pereira, F. V.; Druzian, J. I.; Cellul. Chem. Technol. 2015, 49, 127.

21. Henriksson, M.; Henriksson, G.; Berglund, L. A.; Lindström, T.; Eur. Polym. J. 2007, 43, 3434.

22. Jonasson, S.; Bünder, A.; Niittylä, T.; Oskman, K.; Cellulose 2020, 27, 185.

23. Chimentao, R. J.; Lorente, E.; Gispert-Guirado, F.; Medina, F.; López, F.; Carbohydr. Polym. 2014, 111, 116.

24. Harmsen, P.; Huijgen, W.; Bermudez, L.; Bakker, R.; Literature Review of Physical and Chemical Pretreatment Processes for Lignocellulosic Biomass; Biosinergy: Wageningen, 2010. 
25. Salas, C.; Nypelö, T.; Rodriguez-Abreu, C.; Carrillo, C.; Rojas, O. J.; Curr. Opin. Colloid Interface Sci. 2014, 19, 383.

26. Thiex, N. J.; J AOAC Int. 2012, 95, 1392.

27. van Soest, P. J.; Robertson, J. B.; Lewis, B. A.; J. Dairy Sci. 1991, 74, 3583.

28. Sluiter, A.; Hames, B.; Ruiz, R.; Scarlata, C.; Sluiter, J.; Templeton, D.; Crocker, D.; Determination of Structural Carbohydrates and Lignin in Biomass; National Renewable Energy Laboratory: Colorado, 2008, available at https://www. nrel.gov/docs/gen/fy13/42618.pdf, accessed in December 2020.

29. Segal, L.; Creely, J.; Martin, A.; Conrad, C.; Text. Res. J. 1962, 29, 786.

30. Vanderhart, D. L.; Atalla, R. H.; Macromolecules 1984, 17, 1465.

31. ImageJ, $1.49 \mathrm{o}$; National Institutes of Health, Bethesda, MD, USA, 2015.

32. Ballesteros, L. F.; Teixeira, J. A.; Mussatto, S. I.; Food Bioprocess Technol. 2014, 7, 3493.

33. Pujol, D.; Liu, C.; Gominho, J.; Olivella, M. A.; Fiol, N.; Villaescusa, I.; Pereira, H.; Ind. Crops Prod. 2013, 50, 423.

34. Xu, X.; Liu, F.; Jiang, L.; Zhu, J. Y.; Haagenson, D.; Wiesenborn, D. P.; ACS Appl. Mater. Interfaces 2013, 5, 2999.

35. Collazo-Bigliardi, S.; Ortega-Toro, R.; Carbohyd. Polym. 2018, $191,205$.

36. Reddy, N.; Yang, Y.; Polymer 2005, 46, 5494.

37. Rehman, N.; Miranda, M. I. G.; Rosa, S. M. L.; Pimentel, D. M.; Nachtigall, S. M. B.; Bica, C. I. D.; J. Polym. Environ. 2013, 22, 252.

38. Chen, W.; Yu, H.; Liu, Y.; Carbohyd. Polym. 2011, 86, 453.
39. Tibolla, H.; Pelissari, F. M.; Menegalli, F. C.; LWT-Food Sci. Technol. 2014, 59, 1311.

40. Chen, W.; Li, Q.; Cao, J.; Liu, Y.; Li, J.; Zhang, J.; Luo, S.; Yu, H.; Carbohyd. Polym. 2015, 117, 950.

41. Berglund, L.; Noël, M.; Aitomäki, Y.; Öman, T.; Oskman, K.; Ind. Crops Prod. 2016, 92, 84.

42. Mariño, M. A.; Rezende, C. A.; Tasic, L.; Cellulose 2018, 25, 5739.

43. Kumar, A.; Negi, Y. S.; Choudhary, V.; Bhardwaj, N. K.; J. Mater. Phys. Chem. 2014, $2,1$.

44. Hideno, A.; Abe, K.; Yano, H.; J. Food Sci. 2014, 76, 1218.

45. Mariño, A. M.; Silva, L. L.; Durán, N.; Tasic, L.; Molecules 2015, 20, 5908.

46. de Melo, E. M.; Clark, J. H.; Matharu, A. S.; Green Chem. 2017, 19, 3408.

47. Foston, M. B.; Hubbell, C. A.; Ragauskas, A. J.; Materials 2011, 4, 1985.

48. Park, S.; Baker, J. O.; Himmel, M. E.; Parilla, P. A.; Johnson, D. K.; Biotechnol. Biofuels 2010, 3, 2.

49. Mandal, A.; Chakrabarty, D.; Carbohyd. Polym. 2011, 86, 1291.

50. Aguiar, J.; Bondancia, T. J.; Claro, P. I.; Mattoso, L. H. C.; Farinas, C. S.; Marconcini, J. M.; ACS Sustainable Chem. Eng. 2020, 8, 2287.

51. Yang, X.; Han, F.; Xu, C.; Jiang, S.; Huang, L.; Liu, L.; Xia, Z.; Ind. Crops Prod. 2017, 109, 241.

52. Prakash, M. M.; Selvakumar, R.; Suresh, K. P.; Ramakrishna, S.; RSC Adv. 2017, 7, 42750.

Submitted: August 22, 2020

Published online: December 4, 2020 